\title{
Studi Pendahuluan Ekstraksi Bertingkat Minyak Biji Mangga Arumanis (Mangifera Indica) Menggunalan Pelarut N-Heksan dan Etanol
}

\author{
Fajriyati Masúd $^{1, \mathrm{a}}$ dan Puspitasari ${ }^{1, \mathrm{~b}}$ \\ ${ }^{1}$ Jurusan Teknik Kimia, Politeknik Negeri Ujung Pandang \\ Jl. Perintis Kemerdekaan KM.10 Makassar-90245 \\ afajri@poliupg.ac.id \\ buspa.dj@gmail.com
}

\begin{abstract}
Mango seeds containing oil of about $20-37 \%$, is one source of vegetable oil that has not been touched. Mango seed oil contains polyphenols, so the potential is developed as a functional food. Mango seed oil contains high solid, it can be developed into a product resembling spreadable margarine. The aim of this study was to determine the ratio of solvent, temperature, and time is optimum for extracting mango seed oil. Mango seed oil has been extracted by multistage extraction with hexane and ethanol. Extraction process was performed using reflux method at $30,35,40,45,50,55,60^{\circ} \mathrm{C}$, for $1,2,3,4,5,6$ hours, with solvent ratio of $1: 2,1: 3,1: 4,1: 5,1: 6$. The results showed that the ratio of solvent $1: 4,50^{\circ} \mathrm{C}$ for 4 hours is the best condition for extracting mango seed oil by multistage extraction using $n$-hexane and ethanol..
\end{abstract} Ethanol

Keyword- Mango Seed Oil, Solvent Extraction, N-Hexane,

\begin{abstract}
Abstrak-kernel/biji mangga mengandung minyak sekitar 20-37\%, merupakan salah satu sumber minyak nabati yang belum tersentuh, minyak biji mangga mengandung polifenoldanminyakpadat yang tinggi, sehingga berpotensi dikembangkan sebagai pangan fungsionalberupa produk yang menyerupai margarin olesan. Tujuan dari penelitian ini adalah untuk menentukan rasio pelarut, suhu, dan waktu optimum untuk mengekstraksi minyak biji mangga. Minyak biji mangga telah diekstraksi secarabertingkat dengan n-heksan dan etanol. Proses ekstraksi dilakukan dengan menggunakan metode refluks pada $30,35,40,45,50,55,60^{\circ} \mathrm{C}$, selama $1,2,3,4,5,6$ jam, dengan rasio pelarut 1: 2, 1: 3, 1: 4, 1: 5, 1: 6. Hasil penelitian menunjukkan bahwa rasio pelarut $1: 4,50^{\circ} \mathrm{C}$ selama 4 jam merupakankondisi terbaik untuk mengekstraksi minyak biji mangga.
\end{abstract}

Kata kunci- Minyak Bij Imangga, Ekstrak sipelarut, $\mathrm{N}$-Heksan, Etanol

\section{Pendahuluan}

Buah mangga merupakan produk hasil hortikultura yang sangat digemari dan ditemukan di seluruh pulau di Indonesia.Data Badan Pusat Statistik (BPS) menunjukkan bahwa pada tahun 2015, produksi buah mangga Indonesia yang dapat tercatatsebesar 2.178.833 ton. Tiga jenis mangga utama yang ditanam yaitu Arumanis, Gedong dan Dermayu, sedangkan varietas lainnya dimasukan sebagaimangga sampingan seperti varietas Golek, Manalagi, Bapang dan Kidang [1]. Mangga Arumanis merupakan salah satu buah yang terbaik di pasar dunia, karena rasa yang enak dan aromanya yang harum. Umumnya sekitar 40-60\% limbah buah mangga dihasilkan selama pegolahan dengan 12-15\% merupakan kulit dan 15-20\% merupakan biji/kernel [2]. Padahal biji mangga memiliki potensi untuk dimanfaatkan karena kandungan minyaknya yang tinggi sekitar 16-20\% [3]. Biji mangga mengandung minyak 37 [4]. Minyak biji manggamengandung 44-48\% asam lemak jenuh dan $52-56 \%$ asam lemak tak jenuh, dimana asam stearat merupakan komponen utama asam lemak jenuh dan terkandung sekitar 37,73\%, sedangkan asam oleat merupakan komponen utama dari asam lemak tak jenuh dan terkandung sekitar 46,22\%. Komposisi tersebut sangat baik bagi kesehatan, sehingga minyak biji mangga sangat layak dikembangkan sebagai pangan fungsional [5]. Kajian gizi dan toksikologi dari biji manggamenunjukkan bahwa minyaknya merupakan sumber minyak nabati yang aman, serta bergizi dan tidak beracun sehingga bisa menggantikan lemak padat tanpa 
efek samping [2], hal tersebut menjadi dasarbahwa minyak biji mangga dapat dimanfaatkan sebagai bahan baku untuk pembuatan produk olesan yang menyerupaimargarin yang dapat diklaim sebagai pangan fungsional.

Melihat potensi besar pada minyak biji mangga tersebut, maka penelitian diarahkan untuk mengkaji proses ekstraksinyayang dapat menghasilkan rendemen yang tinggi, khususnya dari biji mangga Arumanis yang ditanam di Sulawesi Selatan. Tujuan penelitian ini adalah untuk mengetahui rasio bahan dengan pelarut, suhu, dan waktu yang optimum pada proses ekstraksi minyak biji mangga. Metode ekstraksi dilakukan secara bertingkat menggunakan metode refluks, pelarut yang digunakan adalah n-heksan dilanjutkan dengan pelarut etanol, dengan demikian diharapkan semua komponen minyak baik yang non polar maupun yang polar dapat terekstraksi dengan maksimal.

Ekstraksi pelarut merupakan proses ekstraksi padatcair atau leaching, yaitu proses pemisahan suatu zat terlarut yang terdapat dalam suatu padatan dengan mengontakkan padatan tersebut dengan pelarut (solvent) sehingga padatan dan pelarut bercampur dan kemudian zat terlarut terpisah dari padatan karena larut dalam pelarut. Pada ekstraksi padat cair terdapat dua fase yaitu fase overflow (ekstrak) dan fase underflow (rafinat/ampas) [6].

Prinsip ekstraksi padat-cair adalah adanya kemampuan senyawa dalam suatu matriks yang kompleks dari suatu padatan, yang dapat larut oleh suatu pelarut tertentu. Beberapa hal yang harus diperhatikan untuk tercapainya kondisi optimum ekstraksi antara lain: senyawa dapat terlarut dalam pelarut dengan waktu yang singkat, pelarut harus selektif melarutkan senyawa yang dikehendaki, senyawa analit memiliki konsentrasi yang tinggi untuk memudahkan ekstraksi, serta tersedia metode memisahkan kembali senyawa analit dari pelarut pengekstraksi [7].

Beberapa faktor yang mempengaruhi kesetimbangan konsentrasi dalamekstraksi yaituperbandingan jumlah sel tanaman dan pelarut, proses difusi sel yang utuh, lama perendaman dan pengembangan sel tanaman, kecepatan proses disolusi sel tanaman yang terintegrasi, kecepatan terjadinya kesetimbangan, suhu dan $\mathrm{pH}$ interaksi senyawa terlarut dan tidak larut, dan tingkat kepolaran pelarut [7]. Jenis dan jumlah pelarut berpengaruh pada rendemen, semakin banyak jumlah pelarut semakin banyak pula jumlah produk yang akan diperoleh, hal ini dikarenakan distribusi partikel dalam pelarut semakin menyebar, sehingga memperluas permukaan kontak, dan perbedaan konsentrasi solut dalam pelarut dan padatan semakin besar [8].

Faktor-faktor yang dapatmempengaruhi proses ekstraksi adalah:

(1) temperature operasi, semakin tinggi temperatur, laju pelarutan zat terlarut oleh pelarut semakin tinggi dan laju difusi pelarut ke dalam serta keluar padatan semakin tinggi pula;

(2) waktu ekstraksi, lamanya waktu ekstraksi mempengaruhi volume ekstrak yang diperoleh, semakin lama waktu ekstraksi semakin lama juga waktu kontak antara pelarut dengan bahan sebagai padatan, sehingga semakin banyak zat terlarut yang terkandung di dalam padatan yang terlarut di dalampelarut;

(3) jenis pelarut, hal ini terkait dengan kepolaran pelarut; (4) jumlah pelarut, semakin banyak jumlah pelarut semakin banyak pula jumlah produk yang akan diperoleh, hal ini dikarenakan distribusi partikel dalam pelarut semakin menyebar, sehingga memperluas permukaan kontak, dan perbedaan konsentrasi solute dalam pelarut dan padatan semakin besar [9].

Pada dasarnya, ekstraksi padat-cair merupakan proses pemisahan solute yang terperangkap di dalam matriks padatan menggunakan suatu pelarut. Mekanisme proses ekstraksi padat-cair diawali ketika pelarut kontak dengan padatan dan kemudian berdifusi eksternal dari fasa bulk menuju ke permukaan padatan berpori. Pelarut kemudian akan melarutkan komponen-komponen terlarut. Setelah itu, terjadi proses difusi internal dimana pelarut akan memasuki pori-pori padatan ke dalam struktur sel dan kembali melarutkan komponen terlarut. Kontak antara pelarut dan padatan sering didukung oleh gaya kapilaritas. Untuk padatan yang berpori, respon ini terjadi sangat cepat $[6,10,11]$.

Solute dapat larut dalam pelarut karena adanya gayaintaraksi diantara molekul-molekulnya, yaitu gaya dipol-dipol dimana zat yang bersifat polar-polar atau non polar-non polar akan saling berikatan. Selain itu juga terdapat gaya London yang terjadi antara dipol-dipol 
yang lemah sehingga memungkinkan pelarut polar melarutkan senyawa non-polar. Bersamaan dengan itu, pori-pori sel akan membesar (swell) sehingga meningkatkan tahanan perpindahan massa. Solute yang terperangkap di dalam matriks partikel padat ini perlu didorong keluar (dalam arah yang berlawanan) dari dalam struktur sel ke pori-pori padatan, yang kemudian menuju ke permukaan padatan, dimana pada saat ini perpindahan massa konvektif terjadi lebih cepat daripada proses difusi dalam partikel. Ikatan yang terjadi antara molekul pelarut dan soluteakan melepas energi yang mendorongnya keluar dan berdifusi menjauhi padatan. Difusi ini terjadi karena konsentrasi pelarut yang mengandung solute lebih besar dibandingkan konsentrasi pelarut di luar padatan yang tidak mengandung solute. Perpindahan massasolute akan terjadi hingga tercapai keadaan setimbang $[6,10,11]$.

\section{Metode Penelitian}

Penelitian dilaksanakan di Laboratorium Kimia Dasar dan Kimia Analisis, Jurusan Teknik Kimia, Politeknik Negeri Ujung Pandang pada bulan September 2016 hingga Januari 2017.

\section{A. Alat dan Bahan}

Peralatan yang digunakan dalam penelitian ini yaitu oven pengering Ecocell, sieving, talang, wadah plastik, timbangan analitik, heater mantel, hot plate, reaktor labu gelas leher empat, oil bath, motor pengaduk IKAWERK RW 20, thermometer, refrigerated centrifuge AX-521, rotavapor Buchi R-215 yang dilengkapi vacuum pomp V-700, botol sampel, dan alat-alat gelas.

Bahan-bahan yang digunakan adalah biji mangga Arumanis yang dipanen pada bulan September hingga Desember 2016 dan diperoleh dari Kabupaten Wajo, Bone, Maros dan Kota Makassar, pelarut n-heksan teknis dan ethanol $96 \%$ yang diperoleh dari toko bahan kimia di Makassar.

\section{B. Prosedur Penelitian \\ 1. Persiapan biji mangga}

Kernel biji mangga Arumanis dipisahkan secara manual dan segera dikeringkan pada oven bersuhu $50^{\circ} \mathrm{C}$, selanjutnya ditepungkan dan diayak pada alat sieving 60 mesh untuk menyeragamkan ukuran bahan, dan disimpan pada kontainer plastik tertutup dalam freezer menunggu proses ekstraksi.

2. Proses ekstraksi minyak biji mangga

a. Perlakuan rasio bahan dengan pelarut

Tepung biji mangga ditimbang $50 \mathrm{~g}$ dalam reaktor labu gelas leher empat, ditambahkan pelarut n-heksan disetiap perlakuan $(1: 2,1: 3,1: 4,1: 5$, dan 1:6). Labu dihubungkan dengan kondensor, thermometer setting, dan motor pengaduk.Labu dipanaskan dalam heating mantel pada suhu $50^{\circ} \mathrm{C}$ selama 5 jam. Selanjutnya bagian padatan dan cairan dipisahkan dengan sentrifugasi pada $3500 \mathrm{rpm}$ selama 20 menit, bagian cairan yang terdiri dari minyak dan pelarut dipisahkan pada rotavapor yang bekerja pada kondisi kecepatan putaran $60 \mathrm{rpm}$, suhu pemanasan $35^{\circ} \mathrm{C}$, dan suhu penguapan $21^{\circ} \mathrm{C}$, sehingga rendemen minyak dapat diketahui menggunakan rumus:

$$
\%=\frac{\text { berat minyak (gv) }}{\text { berat bahan }(\mathrm{gv})} \times 100 \%
$$

Ampas tepung biji mangga selanjutnya diekstraksi lebih lanjut dengan etanol mengikuti prosedur yang sama dengan ekstraksi n-heksan.

b. Perlakuan suhu ekstraksi

Tepung biji mangga ditimbang $50 \mathrm{~g}$ dalam reaktor labu gelas leher empat, ditambahkan pelarut n-heksan dengan rasio 1:4 pada setiap perlakuan.Labu dihubungkan dengan kondensor, thermometer setting, dan motor pengaduk, dan dipanaskan dalam heating mantel pada suhu masing-masing perlakuan $(30,35,40$, $45,50,55$, dan $60^{\circ} \mathrm{C}$ ) selama 5 jam. Selanjutnya bagian padatan dan cairan dipisahkan dengan sentrifugasi pada $3500 \mathrm{rpm}$ selama 20 menit, bagian cairan yang terdiri dari minyak dan pelarut dipisahkan pada rotavapor yang bekerja pada kondisi kecepatan putaran $60 \mathrm{rpm}$, suhu pemanasan $35^{\circ} \mathrm{C}$, dan suhu penguapan $21^{\circ} \mathrm{C}$, sehingga rendemen minyak dapat diketahui. Ampas tepung biji mangga selanjutnya diekstraksi lebih lanjut dengan etanol mengikuti prosedur yang sama dengan ekstraksi n-heksan. 


\section{c. Perlakuan waktu ekstraksi}

Tepung biji mangga ditimbang $50 \mathrm{~g}$ dalam reaktor labu gelas leher empat, ditambahkan pelarut n-heksan dengan rasio 1:4 pada setiap perlakuan. Labu dihubungkan dengan kondensor, thermometer setting, dan motor pengaduk, dan dipanaskan dalam heating mantel pada suhu $50^{\circ} \mathrm{C}$ selama beberapa jam sesuai perlakuan $(1,2,3,4,5$, 6, dan 7 jam). Selanjutnya bagian padatan dan cairan dipisahkan dengan sentrifugasi pada $3500 \mathrm{rpm}$ selama 20 menit, bagian cairan yang terdiri dari minyak dan pelarut dipisahkan pada rotavapor yang bekerja pada kondisi kecepatan putaran $60 \mathrm{rpm}$, suhu pemanasan $35^{\circ} \mathrm{C}$, dan suhu penguapan $21^{\circ} \mathrm{C}$, sehingga rendemen minyak dapat diketahui. Ampas tepung biji mangga selanjutnya diekstraksi lebih lanjut dengan etanol mengikuti prosedur yang sama dengan ekstraksi n-heksan.

\section{Hasil dan Pembahasan}

Ekstraksi minyak pangan (edible oil) dapat menggunakan pelarut n-heksan dan etanol, karena pelarut ini aman dan umum digunakan dalam proses ekstraksi bahan makanan. Etanol disebut juga etil alkohol yang di pasaran lebih dikenal sebagai alkohol yang merupakan senyawa organik dengan rumus kimia $\mathrm{C}_{2} \mathrm{H}_{5} \mathrm{OH}$.Pada suhu ruang etanol berwujud cairan yang mudah menguap, mudah terbakar, tak berwarna dengan titik didih $78,32^{\circ} \mathrm{C}$.Heksan adalah senyawa hidrokarbon alkane dengan rumus kimi $\mathrm{C}_{6} \mathrm{H}_{14}$, dalam keadaan standar senyawa ini merupakan cairan tak berwarna yang tidak larut dalam air, dengan titik didih $69^{\circ} \mathrm{C}$ [12].

Gambar 1, 2, dan 3 memperlihatkan hasil ekstraksi minyak biji mangga menggunakan pelarut $\mathrm{n}$-heksan dan etanol yang dilakukan secara bertingkat. Secara umum dapat dijelaskan bahwa pada minyak biji mangga terdapat komponen polar yang lebih banyak dibanding komponen non-polar, hal tersebut dapat dilihat dari hasil yang diperoleh dimana persentase perolehan minyak hasil ekstraksi etanol lebih tinggi dibanding hasil ekstraksi n-heksana, dari hasil tersebut dapat pula diduga bahwa asam-asam lemak yang menyusun minyak biji mangga didominasi oleh asam lemak rantai pendek.
Asam lemak rantai panjang umumnya baik diekstraksi dengan heksan, tetapi juga tergantung pada batas kelarutannya dalam heksan, namun beberapa asam lemak rantai pendek jugadapat diperoleh dari ekstraksi dengan heksan. Asam lemak rantai panjang cenderung non-polar, polaritas akan menurun dengan bertambahnya panjang rantai karbon. Sebaliknya, asam lemak rantai pendek lebih diekstrak dalam etanol, kelarutannya dalam etanol tergantung pada panjang rantai. Hal ini mungkin menjelaskan mengapa asam lemak rantai panjang agak sulit diekstrak oleh etanol [13].

\section{A. Pengaruh rasio bahan dengan pelarut terhadap rendemen minyak}

Pada proses ekstraksi dengan pelarut, distribusi pelarut ke padatan akan sangat berpengaruh pada perolehan rendemen, perbandingan antara padatan dengan pelarut akan mempengaruhi rendemen yang dihasilkan. Banyaknya pelarut mempengaruhi luas kontak padatan dengan pelarut, semakin banyak pelarut maka luas kontak akan semakin besar, sehingga distribusi pelarut ke padatan akan semakin besar. Meratanya distribusi pelarut ke padatan akan memperbesar rendemen yang dihasilkan, banyaknya pelarut akan mengurangi tingkat kejenuhan pelarut, sehingga komponen yang diinginkan akan terekstrak secara sempurna [14].

Gambar 1 memperlihatkan pengaruh perbandingan bahan dengan pelarut terhadap rendemen yang dihasilkan, dapat dijelaskan bahwa pada suhu $50^{\circ} \mathrm{C}$ selama 5 jam, rendemen minyak biji mangga diperoleh maksimal pada rasio bahan dan pelarut 1:4, baik pada pelarut n-heksan maupun pada etanol, jika jumlah pelarut ditambah maka persentase perolehan minyak akan menurun, hal tersebut terjadi karena jumlah pelarut sudah mencapai titik maksimum untuk mengekestraksi minyak dari tepung biji mangga, dengan kata lain minyak yang terkandung pada tepung biji mangga sudah mencapai batas maksimum kelarutannya dalam pelarut.

Secara umum persentase perolehan minyak mengalami peningkatan seiring bertambahnya jumlah pelarut yang digunakan.Semakin banyak jumlah pelarut yang digunakan, maka semakin besar pula kemampuan pelarut untuk mengambil minyak yang terkandung pada bahan.Semakin banyak jumlah pelarut mengakibatkan 
semakin lama waktu kontak yang terjadi antara bahan dengan pelarut.

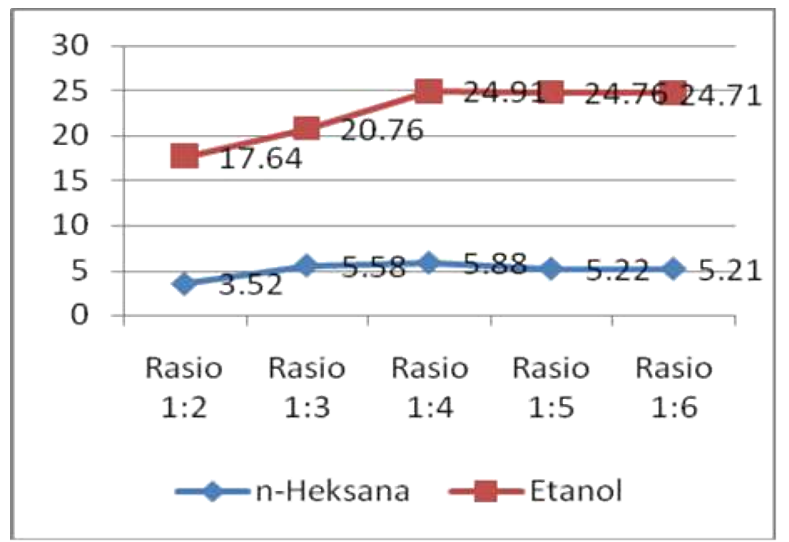

Gambar 1. Rendemen minyak biji mangga pada perlakuan rasio bahan dengan pelarut.

Pada penggunaan pelarut etanol, jumlah etanol berpengaruh terhadap rendemen minyak.Etanol dengan rumus $\mathrm{C}_{2} \mathrm{H}_{6} \mathrm{O}$ memiliki ikatan kovalen polar. Atom $\mathrm{O}$ yang memiliki 2 pasang elektron menyendiri, 1 elektron berikatan dengan $\mathrm{CH}_{2}$ dan 1 elektron lagi berikatan dengan atom $\mathrm{H}$ memiliki rapat elektron yang sangat tidak merata. Etanol yang polar dapat mengekstrak minyak yang non polar karena etanol mengekstrak gugus ester (COO-) yang terdapat dalam minyak [15].

Pada jumlah pelarut yang tetap, semakin besar massa bahan yang diekstraksi maka semakin sedikit pula rendemen yang dihasilkan, hal ini disebabkan oleh berkurangnya kemampuan pelarut untuk mengambil minyak dari bahan seiring semakin besarnya rasio bahan yang diekstraksi. Suatu materi padat dapat mengalami difusi kedalam larutan hingga meningkatkan konsentrasi larutan tersebut. Bahan teresktrak yang berada dalam matriks materi yang inert lambat laun akan terlarut dalam larutan, demikian pula spesies pelarut akan terdistribusi dalam materi padat tersebut hingga mengalami keadaan kesetimbangan [16].

\section{B. Pengaruh suhu ekstraksi terhadap rendemen minyak}

Gambar 2 menjelaskan rendemen minyak biji mangga yang diperoleh mencapai maksimum pada suhu ekstraksi $50^{\circ} \mathrm{C}$. Pada perlakuan suhu 30 hingga $45^{\circ} \mathrm{C}$ diduga masih banyak molekul minyak yang terperangkap dalam jaringan sel. Peningkatan suhu menyebabkan rendemen yang diperoleh lebih rendah, hal tersebut diduga akibat terjadinya degradasi beberapa komponen minyak pada suhu di atas $50^{\circ} \mathrm{C}$. Pada proses ekstraksi, kenaikan suhu mengakibatkan pori-pori pada bahan lebih terbuka sehingga difusi minyak berlangsung lebih cepat karena hambatan difusinya lebih kecil. Ekstraksi padat cair dilakukan pada suhu yang tinggi karena semakin tinggi temperatur, semakin besar konsentrasi solute dalam pelarut. Hal ini disebabkan semakin tinggi temperatur maka viskositas akan semakin rendah dan difusitas solute akan semakin tinggi sehingga semakin cepat dan semakin banyak solute yang berpindah [17].

Pengaruh suhu terhadap proses ekstraksi dapat ditinjau dari kenaikan solubilitas pelarut yang akan memudahkan pelarut masuk dalam pori-pori padatan yang akan diekstrak. Kenaikan suhu dapat menyebabkan terjadinya kenaikan rendemen, semakin tinggi suhu ekstraksi, maka semakin banyak minyak yang dapat terlarut. Proses ekstraksi adalah suatu aplikasi dari proses perpindahan massa, suhu merupakan salah satu faktor yang mempengaruhi kecepatan perpindahan massa. Peningkatan suhu dapat menyebabkan peningkatan solubilitas pelarut dan dapat memperbesar poripadatan, sehingga pelarut masuk melalui pori-pori padatan dan melarutkan komponen padatan yang terjerap kemudian zat terlarut berdifusi keluar permukaan partikel padatan dan bergerak ke lapisan film sekitar padatan, selanjutnya ke larutan [14].

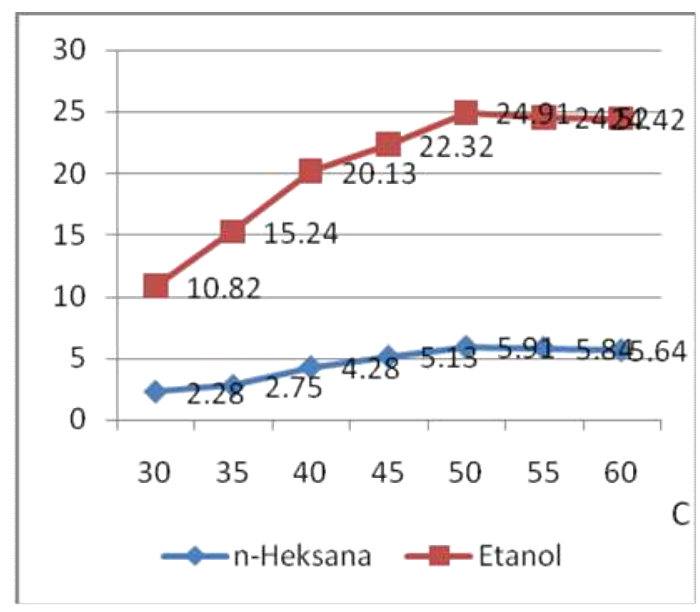

Gambar 2. Rendemen minyak biji mangga pada perlakuan suhu ekstraksi. 


\section{Pengaruh waktu ekstraksi terhadap rendemen minyak}

Gambar 3 menjelaskan bahwa rendemen minyak mencapai maksimal pada waktu proses 5 jam, penambahan waktu menyebabkan rendemen minyak menurun. Waktu ekstraksi sangat mempengaruhi hasil, terutama terhadap nilai transfer massa. Semakin lama waktu kontak antara solute dengan solvent selama proses ekstraksi maka semakin banyak pula jumlah unsur-unsur kandungan kimia yang terekstrak. Lamanya waktu pemanasan akan mempengaruhi kualitas minyak yang diperoleh [18].

Penambahan waktu proses ekstraksi mengakibatkan penambahan jumlah minyak yang dihasilkan. Lamanya waktu akan mempermudah penetrasi pelarut ke dalam bahan, kelarutan komponen-komponen minyak berjalan dengan perlahan sebanding dengan lamanya waktu, dan setelah beberapa waktu jumlah minyak yang terekstrak mengalami penurunan, hal ini disebabkan oleh komponen minyak pada bahan jumlahnya terbatas dan pelarut yang digunakan mempunyai batas kemampuan untuk melarutkan bahan yang ada, sehingga meskipun waktu ekstraksi diperpanjang namun solute yang ada pada bahan sudah tidak dapat melarut lagi.

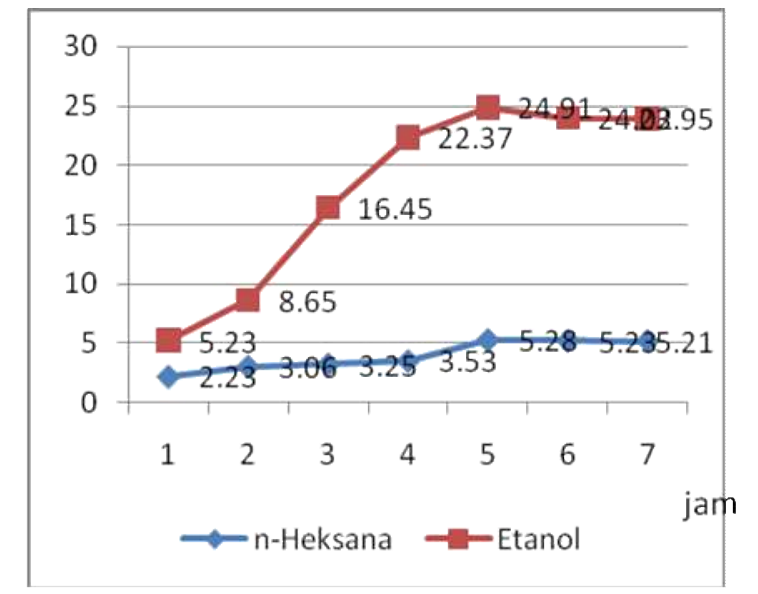

Gambar 3. Rendemen minyak biji mangga pada perlakuan waktu ekstraksi.

Penambahan waktu menyebabkan terjadinya dekomposisi komponen-komponen selain minyak, misalnya impuritas yang menyebabkan perubahan sifat komponen tersebut, misalnya titik didih komponen baru lebih rendah dari titik didih komponen sebelumnya sehingga menjadi lebih mudah menguap dan akhirnya rendemen yang diperoleh berkurang [19].

\section{Kesimpulan}

Pada proses ekstraksi bertingkat minyak biji mangga metode refluks yang bekerja pada kondisi $50^{\circ} \mathrm{C}$ selama 5 jam, rendemen minyak tertinggi diperoleh pada rasio bahan dan pelarut 1:4, baik pada pelarut $n-$ heksan maupun pada etanol. Pada kondisi tersebut diperoleh rendemen minyak sebesar 5,88\% pada ekstraksi n-heksan, dan 24,91\% pada eksraksi bertingkat dengan etanol. Pada rasio bahan dengan pelarut 1:4 dan waktu ekstraksi 5 jam, rendemen minyak tertinggi diperoleh pada suhu $50^{\circ} \mathrm{C}$ sebesar masing-masing 5,91\% dan 24,91\% pada ekstraksi n-heksan dan etanol. Sedangkan pada rasio bahan dengan pelarut 1:4 dan suhu $50^{\circ} \mathrm{C}$ rendemen minyak tertinggi diperoleh pada ekstraksi selama 5 jam yaitu sebesar masing-masing $5,28 \%$ dan $24,91 \%$. Dengan demikian, pada proses ekstraksi minyak biji mangga yang optimum pada rasio bahan dengan pelarut $1: 4$ adalah $50^{\circ} \mathrm{C}$ selama 5 jam.

\section{Ucapan Terima Kasih}

Ucapan terima kasih diberikan kepada badan yang banyak memberikan kontribusi positif bagi penyelesaian penelitian ini termasuk didalamnya sponsor yang membiayai penelitian ini.

\section{Daftar Pustaka}

[1] Supriatna, A., 2007. Kajian Kelayakan Usahatani dan Marjin Tataniaga Mangga (Mangifera Indica) (Studi Kasus Di Kabupaten Majalengka, Jawa Barat).Jurnal Pengkajian dan Pengembangan Teknologi Pertanian X (2):66-178.

[2] Karunanithi, B., 2015. Extraction of Mango Seed Oil from Mango Kernel.International journal of Engineering Research and Development, XI (11).

[3] Messay and Shimeli, 2012. Functional and Physicochemical Properties of Mango Seed Kernels and Wheat Flour and Their Blend for Biscuit Production. African Journal of Food Science and Technolog,. III (9): 193-203.

[4] Yoswathana, N and M. Eshtiaghi, 2014. Extraction of Fatty Acid from Mango Seed kernel Using Supercritical Carbon Dioxide by response Surface Methodology. Asian Journal of chemistry, XXVI (10): 3009-3012.

[5] Fahimdanesh, M. and M. E. Bahrami, 2013. Evaluation of Physicochemial Properties of Iranian Manggo Seed Kernel Oil. IPCBBE LIII. 
[6] McCabe, Warren L.,1993. Operasi Teknik Kimia jilid 2. Erlangga, Jakarta.

[7] Gamse, T., 2002. Liquid-Liquid Extraction and Solid-Liquid Extractionll, Institute of Thermal Process and Environmental Engineering, Graz University of Technology: 2-24.

[8] Munawaroh, Safaatul dan Handayani Prima Astuti, 2010. Ekstraksi minyak daun jeruk purut (Citrus hystrix D.C.) dengan Pelarut etanol dan N-Heksana.Jurnal Kompetensi Teknik, 2 (1): 73-78.

[9] Subriyer Nasir, Fitriyanti, dan Hilma Kamila, 2009. Ekstraksi dedak padi menjadi minyak mentah dedak padi (crude rice bran oil) dengan pelarut $\mathrm{n}$-hexane dan ethanol.Jurnal Teknik Kimia, No. 2, Vol. 16.

[10] Bart HJ dan Pilz, S., 2011, Industrial Scale Natural Products Extraction, Wiley-VCH Verlag \& Co., Germany.

[11] Geankoplis, C.J., 1993, Transpot Processes and Unit Operations, Prentice-Hall International, Inc., New Jersey.

[12] Bustan, MD., Ria Febriyani dan Halomoan Pakpahan, 2008. Pengaruh waktu ekstraksi dan ukuran partikel terhadap oleoresin jahe yang diperoleh dalam berbagai jumlah pelarut organik.Jurnal Teknik Kimia, No. 4, Vol. 15.

[13] Ketaren S. 1985. Minyak dan Lemak Pangan. Universitas Indonesia Press, Jakarta.
[14] Jayanudin, Ayu Zakiyah Lestari, dan Feni Nurbayanti, 2014 Pengaruh suhu dan rasio pelarut ekstraksi terhadap rendemen dan viskositas natrium alginate dari rumput laut coklat (Sargassum sp).Jurnal Integrasi Proses Vol. 5, No. 1: 51-55.

[15] Tedjawicaksana, Teddy.,2004. Pengaruh Temperatur dan Jenis Pelarut terhadap Pembuatan Minyak Kelapa Sawit dengan Ekstraksi Semikontinu. Laporan Hasil Penelitian. Departemen Teknik Kimia. Universitas Katolik Parahyangan. Bandung

[16] Fajriati I, Malawati R, Muzakky, 2011. A Study of Solid-Liquid Extraction with HF And HNO3 as Solvent for Determination of $\mathrm{Cr}$ and $\mathrm{Cu}$ in the River Sediment near the Muria Nuclear Power Plant. Jurnal Ilmu Dasar, Vol. 12 No. 1: 13-22 13.

[17] Tagora BPS, Rinaldry Sirait, Iriany, 2012. Penentuan Kondisi Keseimbangan Unit Leaching pada produksi Eugenol dari Daun Cengkeh. Jurnal Teknik Kimia USU, Vol. 1, No. 1.

[18] Wiyarno, B., RM Yunus and M Mel, 2011. Extraction of Algae Oil from Nannocloropsis sp : Study of Soxhlet and Ultrasonicassisted Extraction, Journal of Applied Science, 11 (21): 36073612.

[19] Guenther, Ernest. 1987. Minyak Atsiri. Jilid I. Jakarta : Penerbit Universitas Indonesia. 